\title{
Pre-9/11 Politics of Islamophobia and Hanif Kureishi's The Black Album (1995)
}

\author{
Malik Haroon Afzal ${ }^{a}$ \\ malikharoonafzal@student.usm.my \\ School of Humanities, \\ Universiti Sains Malaysia, Malaysia \\ Mohamad Rashidi Mohd Pakri ${ }^{b}$ \\ rashidi@usm.my \\ School of Humanities, \\ Universiti Sains Malaysia, Malaysia \\ Nurul Farhana Low Abdullah \\ nflow@usm.my \\ School of Humanities, \\ Universiti Sains Malaysia, Malaysia
}

\begin{abstract}
The rising tide of Islamophobia and the consequent acts of violence pertaining to it over the past couple of years, is inflicting misery on Muslims living across the globe. This situation calls for a clear understanding of the phenomenon of Islamophobia. Using the New Historicist approach, this paper embarks on reading Hanif Kureishi's The Black Album (1995) in the backdrop of the politics of Islamophobia in the pre-9/11 context. It thus attempts to highlight the working of the West-driven anti-Muslim political and literary discourse prevalent during the pre-9/11, or post-Cold-War era. The application of Stephen Greenblatt's thesis of power, subversion and containment enables us to examine the selected novel by situating it within the actual political discourse prevalent during the time of its production to examine its treatment of the Western political narrative of Islamophobia. The study finds that since the 1990s, the West has been relying heavily on the political discourse that intensifies the narrative of Islamophobia in order to contain the subversion it encountered in the form of rising Muslim influence and immigration crises in the West. In the case of literary discourse however, we suggest that while The Black Album (1995) may seem to comply to the Western narrative of Islamophobia, it also offers sights of subversion to the anti-Muslim narrative by exposing Western bias and racist tendencies; and, in return, it ultimately demands negotiation and change.
\end{abstract}

Keywords: Islamophobia; New Historicism; Literary vs Non-literary Texts; Historical Development; Power

\section{INTRODUCTION}

Tanya Basu (2014) traces the origins of the term Islamophobia to an essay by a French author Allan Quellien, published in 1910. According to her, Quellien used "Islamophobie" for the first time to condemn the French colonizers' injustices towards their Muslim colonies, particularly Algeria. L. P Sheridan (2006) notes that the word 'Islamophobia' appeared some 90 years later in English, and was first included in the Oxford Advanced Learner's Dictionary in 1997. That same year the Runneymede Trust, a British intelligence company, defined Islamophobia as "a shorthand way of referring to dread or hatred of Islam — and, therefore, to fear or dislike of all

${ }^{a}$ Main author

${ }^{b}$ Corresponding author 
or most Muslims" (Report, p. 3). Similarly, Nadeem F. Paracha (2019) while providing a brief background of Islamophobia observes that the massive migration to Europe after 1970 and the 1973 oil crisis gave a boom to race riots - driven by the neo-fascist groups and motivated by deteriorating economies - that accorded Muslims the status of the 'other' by fanning the fire of migration problem. He opines that after the 1990s, when Muslims claimed the 'otherness' accorded to them in the first place by the West, the migration problem transformed into a religious problem. It was during this time when "the presence of veiled women and mosques grew", and "'migration problem' began to be considered as the 'Muslim problem', triggering Islamophobia" (Paracha, 2019, p. 4). However, after providing a detailed history of Islamophobia, Paracha (2019) views the concept as a "handy tool for populist politicians to make Muslims the scapegoats for the economic or cultural decline in the West" (p. 6). Similarly, the recent surge of Islamophobia in the Western context that manifested itself in the form of incidents of anti-Islamic violence and rhetoric such as the New Zealand mosque attacks, the Quran burning incident in Norway, and the stereotyping of Muslims by Western leaders (including Donald Trump and Emmanuel Macron et al.) has also given rise to a debate within academic circles about the populist politicians who are fanning the flames of Islamophobia in fulfilment of their respective political agendas (Azhar 2019; Curvi, 2020; Klaas 2019; Paracha, 2019; Saad, 2020).

In the field of the humanities, researchers have attempted to read the phenomenon of Islamophobia from the perspective of an us/other dichotomy (Chauhan, 2005; Kumar, 2012; Wolf, 2015), while others studied it with reference to Islamic imperialism (Othman, 2014; Rana, 2007). Anglophone literature has also been read using the same lens of Orient/Occident as well as from the angle of mistreatment of the diasporic Muslim communities (Abubakar et al., 2019; Morey, 2018; Zaidi \& Sahibzada, 2018). Working from a similar perspective, the current debate on Islamophobia in Pakistani Anglophone literature seems to have missed out the contribution of political and literary discourse towards the construction and development of Islamophobia (Banerjee, 2020; Langah 2019; Morey, 2018; Quin 2018; Riaz 2017; Haidar, 2012). For example, Nukhbah Taj Langah (2019) reads Islamization and post-9/11 Islamophobia through Pakistani literary and non-literary responses. She endeavours to do two things in her work: first, she "deconstructs and connects Islamization and Islamophobia as two key processes which impacted Muslim-Pakistani identity in the aftermath of 9/11" (p. 79); secondly she challenges the "repetitive reliance on fiction for understanding the post-9/11 discourse" (Langah, 2019, p. 80). Although Langah (2019) attempts to study Islamophobia in contemporary Pakistani literature by linking it with Islamization in Pakistan. Neither of the two aspects of her research deals with the role and contribution of the literary and non-literary discourses in the construction of the narrative of Islamophobia.

Similarly, Humaira Riaz (2017) studies racism and Islamophobia in the selected American literary texts. She uses "Fredrickson's notion of racism 'as scavenger ideology", and "unveils racism incorporated in Islamophobia in fiction" (Riaz, 2017, p. 7). By doing so, she misses out on exploring the actual role of discursive formations in the construction and development of Islamophobia. As such, in the effort to fill this gap, this paper strives to investigate the impact of pre-9/11 and post-Cold War era power politics on the rise and development of Islamophobia in the West with reference to Hanif Kureishi's The Black Album (1995). This era has been selected because it is marked by a sudden outburst of anti-Muslim sentiments. For example, as discussed above - in Paracha's (2019) words - after the 1990s when Muslim influence increased in the West, the immigration problem transformed into a religious problem. In addition to this, the chronological survey of Islamophobia also demarcates the post-Cold war and pre-9/11 era from others as it shows a surge in anti-Muslim sentiments in the West. The Runnymede Trust's report points out the same shift in the behaviour of the West towards Islam as follows: 
"It is no accident, some commentators have suggested, that the recent demonizing of Islam began at much the same time that the "evil empire" of communism receded as a real threat. Western political and popular culture required a new enemy, an implacable other, to replace the Soviet Union. Also, it is cynical if plausibly claimed, the Western armaments industry needed a new enemy" (Report, 1997, p. 8).

By according the role of 'power' to the West, this paper studies the dynamics of power relations using the lens of Stephen Greenblatt's New Historicist approach to show the way in which power contributed to the development of Islamophobia by using the discursive formations (both literary and non-literary or political). Hence, we aim to investigate the working of the literary and non-literary discourses prevalent in the pre-9/11 era that hypothetically promoted the narrative of Islamophobia and constructed Islamophobic selves. By doing so, the study will not only provide the contextual historical development of Islamophobia, but will also provide the textualization of it in the contemporary Pakistani Anglophone fiction.

\section{LITERATURE REVIEW: POLITICAL TAPESTRIES OF PAKISTANI LITERATURE}

In order to define and review Pakistani Anglophone writers, we rely on Cara N. Cilano's Contemporary Pakistani Fiction in English: Idea, Nation, State (2013), and Muneeza Shamie's Hybrid Tapestries: The Development of Pakistani Literature in English (2017). Muneeza Shamsie (2017) divides Pakistani Anglophone writers into two groups: the first group comprises the pioneering writers such as Hanif Kurieshi, Zulfikar Ghose, Tariq Ali and Sarah Suleri; whereas the second one is the group of writers belonging to the younger generation. These writers are: Nadeem Aslam, Mohsin Hamid, Kamila Shamsie, and Uzma Aslam Khan. Similarly, Claire Chambers (2011) had described Bapsi Sidhwa, Hanif Kureishi and Zulfikar Ghose as "leading luminaries of Pakistani writings in English" (p. 123). Her list of the younger generation of the Pakistani Anglophone writers included Nadeem Aslam, Mohsin Hamid, Kamila Shamsie, and Muhammad Hanif. It is important to note here that most of these authors have a foreign background as they belong to the Pakistani diasporic communities of England and America. Accordingly, Muneeza Shamsie $(2017$; 1997) points out that the hybrid background of these authors is not a reduction of their Pakistani identity, rather it is an intensifier in their ability to write out of the box. She says that "Pakistani English literature, particularly fiction" stands "on the brink of a new horizon", and that "[i]n today's globalized world there are only a few dividing lines between 'resident' and 'diaspora' writers of Pakistani origin" (Shamsie, 2017, p. 6). According to her, due to the hybrid nature of the writers' background and exposure, her "definition of 'a Pakistani writer' continues to be that of anyone who claims that identity" (ibid). This indirectly confirms Chambers' (2011) suggestion that the hybrid backgrounds of these writers allows them to "exhibit an ability" to "live between East and West, literally or intellectually" (p. 123).

Due to this hybrid experience according to the aforementioned anthologies, the Pakistani Anglophone fiction writers are able to not only deconstruct and decode various factors fuelling the fire of religious extremism in Pakistan, but also offer important insights for the analysis and examination of factors jeopardizing the stability and solidarity of today's world. In the context of the current geo-political crisis, the Pakistani Anglophone fiction writers have emerged on the literary scene as political commentators and are striving to deconstruct the hegemonic discourses by providing alternative perspectives, as well as appropriating the prevailing discursive and cultural preoccupations about Pakistan and its people. Moreover, the contemporary Pakistani Anglophone literature, by using literary tradition of the former colonizers, delves into its national history to expose the causes of the country's current 
economic and socio-political crisis. In this regard, Ali Usman Saleem (2015) argues that "it is pertinent to see how these writers reflect and question the issues of national and political significance and how their writings imagine developing a national identity for their people by intervening in the more powerful and hegemonic Western discourse" (p. 12).

Nevertheless, in Pakistani Anglophone fiction's quest for the reflection of issues related to the political and national significance and its struggle at undoing the Western hegemonic discourses, Hanif Kureishi, Mohsin Hamid, and Kamila Shamsie hold an eminent position. For example, Huggan (2003) writes that Kureishi's writings foreground the "tension with the imperial power" and encapsulate all the problems of "immigration, displacement, racial and cultural discrimination" in his works, particularly in the context of Pakistani/Indian diaspora in England (p. 13). On the other hand, Mohsin Hamid's writing is described as "underlining the dangerous situation of orientalism's asymmetrical knowledge, where the other is well informed about the self, while the centre knows relatively little about the periphery" (Lau \& Mendes, 2018, p. 84). Similarly, the richness of Kamila Shamsie's technique is reflected "in the ways in which varied themes and stories within a novel are multilayered, interact and are part of each other, so that the narrative about a person or a couple is viewed within a larger, more socially dense context" (King, 2011, p. 147).

Peter Morey (2018) in his seminal work Islamophobia and the Novel discusses the impact of Islamophobia on the contemporary Anglophone novel. Drawing on the critiques of some of the eminent theorists such as Theodor Adorno, Edward Said, and Gayatri Chakravorty Spivak, he examines Islamophobia in some selected novels. Besides three English writers Martin Amis, Ian McEwan, and John Updike, Morey (2018) discusses five Pakistani writers in his monograph including: Hanif Kureishi, H. M. Naqvi, Nadeem Aslam, Kamila Shamsie, and Mohsin Hamid. He shows the relationship between Islamophobia and the power politics of West and its subsequent representation in the contemporary novel. Despite its undeniable wideranging coverage of the problem of Islamophobia with reference to the contemporary novel, the study still has some limitations: the selected texts have not been examined against the backdrop of the actual political discourse produced during the time of their production. By such omission, Morey's study seems to disregard power's control over the literary and non-literary discourses. Other studies appear to have also examined Islamophobia in the contemporary Anglophone fiction in terms of globalization, neo-imperialism, and fundamentalism with similar theoretical approaches as used by Morey (Banerjee, 2020; Quin 2018; Haidar, 2012). For example, Debjani Banerjee (2020) studies British Muslim identities in Kamila Shamsie's Home Fire with a "transnational framework" (p.1), whereas Emelia Quin (2018) studies Islamophobia in Shamsie's Burnt Shadows through a "vegan lens" maintaining that "speciesism has been foundational to the assertion of an "us" versus "them" dichotomy" (p. 109). In the same way, Nishat Haidar (2012) mapped the traces of Islamophobia in "Globalization, US Imperialism and Fundamentalism" with reference to Mohsin Hamid's The Reluctant Fundamentalist by utilizing "the Clash of Civilizations theory" (p. 203).

Looking critically at the overall body of research carried out on the Pakistani Anglophone fiction in the context of Islamophobia, it has been found to have contributed significantly to the already existing body of knowledge regarding the issues of Islamic fundamentalism, racism, terrorism and ethnocentrism. Researchers have approached these texts with multiple lenses. They have explored racism, ambivalence, multiculturalism, politics, and Islamophobia with postcolonial and cultural theories. None of the studies, however, to the best of our knowledge, has explored and examined texts using the New Historicist approach, and therefore, have not studied it in the context of actual non-literary discourse about Islamophobia. In sum, the relation of Islamophobia, particularly against the backdrop of the New Historicist approach is conspicuously missing in the body of research on Pakistani Anglophone literature. 


\section{NEW HISTORICISM AND ISLAMOPHOBIA}

This paper draws its methodology from New Historicism to examine the selected novel. New Historicism as explained by John Brannigan (1998), is "a mode of critical interpretation" that deals with literary texts as the locus of "power politics" while considering the "power relations as the most important context for texts of all kind" (p. 6). Ann B. Dobie (2012) while discussing New Historicism asserts that it is about examining and understanding a text "by examining its cultural context -the anxieties, issues, struggles, politics (and more) of the era in which it was created" (p. 181); as such, a New Historicist critic is the one who takes literature as an instrument to comprehend the culture in which it is written. Keeping in view this definition of New Historicism, the study examines Islamophobia in Kureishi's selected novel, produced during the post-Cold War era (1990 onwards) by situating it in its actual political context. By doing so, we aim at utilizing its "historicity and textuality" (Montrose, 1997) to examine its treatment of Islamophobia. To do so, The Black Album (1995) by Hanif Kureishi will be examined in the next section against the backdrop of the findings of the Runneymede Trust Report on Islamophobia entitled Islamophobia: A Challenge for Us All (1997).

Hence, the examination of the selected Anglophone Pakistani novel will also enable us to examine the "cultural context -the anxieties, issues, struggles, politics (and more) of the era in which it was created" (Dobie, 2012, p. 181). In addition, the study of Islamophobia against the backdrop of Greenblatt's constructs of power, subversion and containment will also elicit an interpretation of powerplay with reference to Cold war politics. Michael Foucault (1981) famously asserted that "Power is everywhere; not because it embraces everything, but because it comes from everywhere" (p. 93). In turn, Greenblatt borrows this notion of power from Foucault and extends that power's autonomy and pervasiveness that depends upon its ability to contain any kind of subversion it comes across, and posits that power contains transgression with the help of linguistically and ideologically constructed selves. In his book Renaissance Self Fashioning (1980) Greenblatt theorises that the ideological self, once created, controls and directs its own social and political behaviour by complying to the dominant ideology as well as by keeping a watch on its flow. By doing so, ideology simultaneously excludes yet subtly enforces coercion. John Brannigan (1998) adds:

"[T] he self-polices and regulates its own desires and repressions. This removes the need for power to be repressive. No physical or military force needs be deployed or exercised for power to have operated effectively in the interests of dominant ideological systems when the self, ideologically and linguistically constructed, will reproduce hegemonic operations" (p.7).

According to New Historicism, the containment of subversion and the development of linguistically and ideologically created selves are done at the level of representation (Wilson, 2007). For Foucault (1972), representation is, "the general set of rules that govern their objects" (p. 115). He opines that representation is a system that hegemonizes the way its subjects are "institutionalized, received, used, re-used, combined together, the mode according to which they become objects of appropriation, instruments for desire or interest, elements for a strategy" (Foucault 1972, 115). Nevertheless, Greenblatt develops and links this phenomenon of representation with prevailing literary and non-literary formations of a society and maintains that the construction of the linguistically and ideologically, constructed selves is not possible without these discursive formations, and therefore containment of any kind of subversion. He asserts:

\footnotetext{
"My interest in what follows is in a prior form of restraint - in the process whereby subversive insights are generated in the midst of apparently orthodox texts and simultaneously contained by
} 
those texts, contained so effectively that the society's licensing and policing apparatus is not directly engaged" (Greenblatt, 1981, p. 41).

Keeping in view this scholarship of New Historicism, we aim to study the construction of Islamophobia in comparison with the selected literary and political (non-literary) texts published since the end of the Cold war, and to know the way these discursive formations that in Greenblatt's words are "orthodox texts" (ibid) helped power in containing the subversion it confronted in the form of the rise of Muslim influence in the West. However, the debate also begets the question that how the narrative of Islamophobia has been supported by the Pakistani Anglophone literature, particularly Kureishi's The Black Album (1995).

Undoubtedly, the critique of New Historicism renders a godlike status to power that neglects the potency of subversion". Greenblatt (1981) maintains in Invisible Bullets that "the production of subversion is the very condition of power" that empowers it to justify its policies as well as makes itself noticeable (p. 57). The impotency of subversion and the dominant status of power in the New Historicist approach makes it questionable in the eyes of critics. However, Brannigan (1998) tries to clarify the situation by saying that, "New historicists usually see their practice as one of exposition, of revealing the systems and operations of power so that we are more readily equipped to recognise the interests and stakes of power when reading culture" ( $p$. 8 ) and "It is one of the legacies of new historicism, then, to have recognised the ways in which power produces and contains what appears to be its opposite, or what seems to be a radical difference" (1998, p 150).

Not only this, some critics are also susceptible to the possibility of negotiation in the tug of war between power and subversion. For them, subversion is not always passive (Grady, 1993; Motlagh, 2015). For example, Motlagh (2015) asserts that, "Greenblatt does not render a totally pessimistic idea through this process, however he represents a model in which there are chances for negotiations, thus there would be some opportunities for resistance and change" (p. 215). In the same way, Grady (1993) affirms the possibility of "negotiation" between power and subversion in his essay "Containment, Subversion -and Postmodernism" (p.37). By contextualizing Shakespeare's King Lear, he maintains that "the Renaissance theatre was both under the duress of power and able to escape from underneath it by virtue of the cracks and fissures, the confusions and contradictions, that constituted power in that (and every other) epoch" (p. 39). In this context, we also hypothesize at this stage that the Pakistani Anglophone literature does not comply with all the policies set by the power, and by doing so it offers a possibility of negotiation.

\section{PRE-9/11 POLITICS OF ISLAMOPHOBIA, AND HANIF KUREISHI'S THE BLACK $A L B U M(1995)$}

In this section, we examine the way the literary and the non-literary discourse produced during the post-Cold War era aided the development of Islamophobia with particular reference to The Black Album (1995) and the Runneymede Trust's report (1997). We rely heavily on the Runneymede Trust's report because it is a seminal document that covers all aspects of antiMuslim political discourse that appeared in the Western media in the Post-Cold War era. The analysis of the selected novel in the backdrop of the Runneymede Trust's report aims at answering the questions as to in what way Kureishi's portrayal of Muslims in his novel complies to the Western definition of Muslims and Islam, and how the novel registers and represents the political narrative of its time.

\footnotetext{
"New historicism often makes for grim reading with its insistence that there is no effective space of resistance. Because no self, group or culture exists outside language or society, and because every language and society are self-policing, hegemonic systems, there is no possibility of resistance emerging unchecked" (Brannigan, 1998, p.8).
} 


\section{ISLAM AS A MONOLITHIC AND STATIC RELIGION}

According to the Runnymede Trust's report, Islam had been accorded an image of a monolithic and static religion (by the prevailing political discourse of the West) which did not have the capacity to adapt to cultural diversity. The report states that the closed view about Islam that was depicted primarily in the print media depicted Islam as "undifferentiated, static and monolithic, and as intolerant of internal pluralism and deliberation" (1997, p.5). Islam was represented to be a religion with tensions not only with the West but included intra-religious tensions which were also associated with Islam. It says that Muslims "ignore debates about human rights and freedom in Muslim countries and contexts, and about appropriate relationships between Islam and other world faiths, and between Islam and secularism" (ibid). In other words, the report views Islam as a "single monolithic bloc, static and unresponsive to new realities", and is "intolerant of internal pluralism and deliberations" (ibid). For example, under Runnymede Trust report's categorization of Islam as a 'monolithic and static religion', it is defined on the basis of its tensions with secularism, human rights, and freedom. It is portrayed as a single bloc with no diversity. In other words, the West imagines Muslims to be the followers of a religion which is so rigid that it offers little or no possibilities for change. Whether it is about "the interpretations of historic beliefs, the nature and role of symbols, the authority of scriptures", or about "lifestyle, cultural customs, personal morality, politics, and social justice", according to the Western view of Islam, it holds little space for new realities and therefore no room for "progressiveness" (p. 6).

Our analysis of the novel reveals similar nuances of anti-Muslim political narrative as represented by the Runneymede Trust's report. In the jargon of New Historicism, Hanif Kureishi "textualizes and historicizes" (Montrose, 1997) the political narrative of Islamophobia in his novel The Black Album. For example, from the very beginning of the novel, the first intra-religious disagreement appears on the matter of Hat's choice of profession, as to whether or not he should opt for accountancy. According to Chad, "accountants have to meet many women. And shake hands with them. They are expected, too, to take alcohol everyday and get involved in interest payments" (Kureishi, 1995, p. 91). On the other hand, Shahid persuades him to try his best to be an accountant. For him, Hat would regret it, if he doesn't pass his accountancy exams because "there must be more to living than swallowing one old book" and "What men and women do, and the things they make, must be more interesting than anything that God is supposed to do" (Kureishi, 1995, p. 272). As mentioned above, Islam's position as a monolithic and static religion is defined on the pretext of its confrontation with new realities; the reader thus finds the debate about Hat's profession epitomizing a similar kind of intrareligious tension between two groups in which one is presenting itself to be rigid by imposing an unchanged and static connotation of the banking profession, whereas the other has the desire to adopt to new realities and struggles to escape that static and monolithic state. In addition, the novel textualizes the tension between two Muslim fraternities: one a group of orthodox believers who outrightly outcast the banking profession as it involves interest payments (Khan, 2011) and the others who considers Islam to be adaptable to 'new realities' and therefore progressiveness (Sadeghi, 2017).

On another occasion in the novel the mutual conflict and tension among Muslims as constructed by the Western political discourse, appears in the arguments of Tahira and Chad regarding the proper way of clothing. Their arguments construct the image of conflicting practices between Muslim men and Muslim women with no mutual respect. Tahira while objecting on Chad's tight trousers asserts that "You brothers urge us to cover ourselves but become strangely evasive when it comes to your own clothes. Can't you wear something looser?" (Kureishi, 1995, p. 105). She further says "aren't you thinking of growing some beard? (ibid). Under the category of 'Islam as monolithic and static religion' Islam is viewed as an 
'imposingly rigid' religion that shows little acceptance for new realities on all social and political matters including "gender issues and roles" (Report, 1997, p. 6). The examples of Chad and Tahira's arguments underscore the tension among Muslims regarding "gender issues and roles" (ibid) in which Chad is free to wear whatever he wishes, whereas the females like Tahira are still not accorded an equal amount of freedom. However, by having these characters embody the characteristics of anti-Muslim narrative as reported in the Runneymede Trust's report about Islamophobia, these examples from the novel conspicuously demonstrate that The Black Album complies to the Western political narrative about Muslims as followers of a monolithic and static religion. Moreover, throughout the novel, the practicing Muslim characters (Riaz, Chad and Hat) are portrayed as people with monolithic and rigid ideas. For example, while talking about homosexuals, Hat shows an extremist mind-set in demanding their beheading while Riaz affirms their eternal punishment by God, saying that "God would burn homosexuals forever in hell, scorching their flesh in the furnace before replacing their skin as new, and repeating this throughout eternity" (Kureishi, 1995, p. 119). The same ferocity appears in their reaction to the blasphemous book published in England. Riaz can be seen justifying the violence at that incident where he asserts that "Sometimes there is violence, yes, when evil has been done" (Kureishi, 1995, p. 173). For him the punishment for the offender should at least be stoning till death (Kureishi, 1995, p. 172). As obvious from these examples, Kureishi's characters are portrayed to be compliant to the description of Muslims as the ones "intolerant of internal pluralism and deliberation" and the ones professing "monolithic and rigid ideals". In this way the novel can therefore be seen to exemplify Greenblatt's notion of orthodox texts (literary and non-literary) that comply to the dominant narrative set by power.

\section{ISLAM AS THE 'OTHER'}

The second most important finding of the Runneymede Trust's report is West's stigmatization of Islam as the 'other'. The West viewed Islam and the rest of the world from a binary perspective, where Islam was an alien religion professing an altogether different set of ideologies and practices which had no capacity to mix and absorb. The Report states, "Islam is 'other', with few or no similarities between itself and other civilizations and cultures, and with few or no shared concepts and moral values", and that it is seen as "hermetically sealed off from the rest of the world, with no common roots and no borrowing or mixing in either direction" (1997, p. 6). In the novel, the characters of Riaz and Chad project the same image of Islam as the 'other'. The version of the religion that they advocate in the novel creates an image of the 'other' that is precisely isolated and has no capacity to absorb any culture and therefore is "sealed off from rest of the world" (ibid). For example, Chad remarks as follows about the Whites:

\footnotetext{
"They are existing at the lowest level! And we think we want to integrate here! But we must not assimilate, that way we lose our soul. We are proud and we are obedient. What is wrong with that? It's not we who must change, but the world!” (Kureishi, 1995, p. 81).
}

It can also be seen here that Chad thinks that Muslims do not want to integrate in the Western society because the West is "existing at the lowest level" (ibid). By doing so, he conforms to the narrative that Islam is "sealed off from rest of the world, with no common roots and no borrowing or mixing in either direction" (Report, p. 6) by differentiating Muslims from the rest of the world. Similarly, Riaz also comments that "Gluttony, nihilism, hedonism capitalism in a nutshell. Along with it, we are witnessing the twilight of Communism. Those revolutionaries weren't even able to achieve socialism in one room. Altogether we are seeing the shrivelling of atheism" (Kureishi, 1995. p. 33). It can be seen that just like the insensitivity of Chad towards the West, Riaz too exaggerates the negative side of Western society and 
espouses hatred and hostility for the West, that in no way allows for the possibility of integration - thereby strengthening the image of the other. Hence, the rigidity and inflexibility in Islam as portrayed by these characters as well as their tone can be assumed to have complemented the part of Western political discourse that views Islam as an isolated other.

\section{ISLAM AS INFERIOR}

The Western political narrative portrayed Islam as 'inferior'. The difference between Islam and the West was considered to be the difference between civilized/uncivilized, and rational/irrational etc. The Report indicated that the Western narrative viewed the West as "civilized, reasonable, efficient, sophisticated, enlightened, non-sexist", whereas Muslims were portrayed to be "primitive, violent, irrational, scheming, disorganized and oppressive" (1997, p. 6). In the novel, this Western bias against Islam can be spotted in the utterance of Professor Brownlow who while having a conversation with Riaz describes him as "[ $\mathrm{t}]$ he slave of superstition" (Kureishi, 1995, p. 97). This irrational image of Islam that has been constructed by the Western narrative of Islamophobia, can be witnessed in his complete utterance: "Wonderful on one's knees. Existing in an imaginary realm ruled by imaginary beings. Wonderful to have all rules of life delivered from on high. What to eat. How to wipe your bottom... how abhorrent too! The slave of superstition" (Kureishi, 1995, p. 97). Nevertheless, at this point the novel seems to be responding to and challenging the Western political imagination as Riaz provides an anti-thesis to Brownlow's assertion:

\footnotetext{
"Your liberal beliefs belong to a minority who live in northern Europe. Yet you think moral superiority over the rest of mankind is a fact. You want to dominate others with your particular morality, which has - as you also well know - gone hand-in-hand with fascist imperialism...This is why we have to guard against the hypocritical and smug intellectual atmosphere of Western civilization" (Kureishi, 1995, pp. 98-99).
}

However, by looking critically at the plot and overall narration of the novel, we suggest that although the blame of irrationality that can be viewed in the dialogue of Brownlow, has been well rebutted by Riaz, the novel's description of Muslims as primitive and irrational, and its compliance to the normative of Islamophobia renders it still suspicious. The narrative of the emergence of a miraculous aubergine with holy inscriptions imagines Muslims as superstitious, primitive and irrational who can believe in anything: "He told them that a devout local couple had cut open an aubergine and discovered that God had inscribed holy words into the mossy flesh. Moulana Darapuria had given his confirmation that the aubergine was a holy symbol" (Kureishi, 1995, p. 171). No doubt the incident criticizes the superstitious tendency of the Muslim community, but at the same time it affirms the narrative of irrationality that was and is still being used to justify Islam as an irrational religion. In reality, the incident may refer only to a fraction of Muslims dominated by such beliefs, but the association of the whole Muslim community with the aubergine celebration in the novel is still problematic and affirms Kureishi's compliance to the normative of Islamophobia.

Nevertheless, besides exposing Kureishi's compliance to the normative of Islamophobia, it also shows up Western intolerance towards Muslims and Islam. Later, in the novel we come across several instances where the Muslim community who celebrates that holy aubergine becomes a site of ridicule and mockery at the hands of the whites. George Rugman Rudder comments, "What a marvellous crowd, worshiping the fruit of the earth! what a popular aubergine, top of the vegetable table! What a sound method of communication the miracle is! Thank God a Tory Borough wasn't chosen!" (Kureishi, 1995, p. 177). And later he comments that "Of course, revelations are faith's aberration, an amusement at the most. Let's hope they curry this blue fruit. Brinjal, I believe it's called" (Kureishi, 1995, p. 179-80). However, the 
lesson of cultural relativity and respect for others' culture, values and traditions promoted and preached by the West can be witnessed as the empty signifiers that they are in the present case. In addition to this, Deedee's associating of the Muslim community's sacred object with the genitals of her lover is a clear example in this regard. She says, "Give me your aubergine. Fill my cock-shaped hole... Stick it in my earth and let me bless it with my holy waters" (Kureishi, 1995, p. 212). However, the description of Muslims by Kureishi in The Black Album, beginning from the communal meeting of Riaz and company, to their planning to guard the attacked Bengali family; and from their reaction towards the blasphemous book to their attack on Shahid, affirms and proves them to be "primitive, violent, irrational, scheming, disorganized and oppressive"(ibid).

\section{ISLAM AS AN ENEMY}

Based on the assumptions of violence, irrationality, and oppression, Western narrative in the pre-9/11 context rendered Islam an antagonist status and declared it an enemy. The Report notes that Islam is seen as "violent and aggressive, firmly committed to barbaric terrorism, and implacably hostile to the non-Muslim world" (1997, p. 7). In the novel, the use of violent expressions by the Muslim characters such as "we are going for the wrath" (Kureishi, 1995, p. 87) and "We should call ourselves the Foreign Legion" (Kureishi, 1995, p. 82) confirm them as the proponents of a religious that is violent, aggressive and "firmly committed to barbaric terrorism" (1997, p.7). Riaz says, "We are not blasted Christians. We don't turn the other cheek. We will fight for our people who are being tortured in Palestine, Afghanistan, Kashmir! War has been declared against us. But we are armed' (Kureishi, 1995, p. 82). The representation of Muslims as implied extremists by the above laundry list of sites of religious conflict marks Kureishi's questionable stance in embodying his characters with the anti-Muslim Western narrative about Islam while validating the scholarship of New Historicism on the other. This is because according to the tenets of New Historicism, the containment of subversion and the development of linguistically and ideologically created selves are performed at the level of representation. As explained earlier, Greenblatt (1981) develops and links this phenomenon of representations with prevailing literary and non-literary formations of a society and maintains that the construction of the linguistically and ideologically inflected selves is not possible without these discursive formations and therefore, containment of any kind of subversion. He accords the status of "orthodox texts" to these discursive formations that to him, contain the subversion in a way that "the society's licensing and policing apparatus is not directly engaged" (Greenblatt, 1981, p. 41). Keeping in view this articulation of New Historicism, these characters' conformity to the Western political narrative of Islamophobia, seem to be placing The Black Album (1995) within the category of those "orthodox texts" that enabled the power to contain the subversion it confronted in the form of the rise of Muslim influence in the West.

\section{MUSLIMS AS MANIPULATIVE}

Similarly, the Runnymede Trust's report about Islamophobia also suggests that the Western political discourse about Muslims viewed them as manipulative, and therefore questioned their loyalty. "It is frequently alleged that Muslims use their religion for strategic, political and military advantage rather than as a religious faith and as a way of life shaped by a comprehensive legal tradition" (1997, p. 8). A similar thesis can be seen in the novel when the narrator introduces Riaz and his communal meetings with other members of Muslim community. The pet titles of Riaz's speeches, "Islam: A Blast from the Past or a Force for the Future" and "Democracy is Hypocrisy" (Kureishi, 1995, p. 80) suggest the confirmation of the Western political narrative that renders Islam as a manipulative religion which aims at gaining 
strategic, political and military advantage. It is interesting to note that the former speech title "Islam: A Blast from the Past or a Force for the Future" seemingly foreshadows Samuel Huntington's widely cited thesis The Clash of Civilizations and the Re-making of World Order (1996) in which Huntington - while referring to the military invasions of the Ottoman empire - proves Islam as a political and military force and Muslims as a people using "their religion for strategic, political and military advantage" (ibid). As he asserts, "The underlying problem for the West is not Islamic fundamentalism. It is Islam, a different civilization whose people are convinced of the superiority of their culture and are obsessed with the inferiority of their power" (Huntington, 1996, p. 217). Readers today who come across such titles as "Islam: A Blast from the Past or a Force for the Future", and "Democracy is Hypocrisy" will immediately associate them with conforming to the Western political narrative about Islamophobia - as depicted in the report as well as in Samuel Huntington's scholarship — on the one hand, and its "textualization and historicization" of the Western political narrative about Islam, on the other.

In sum, we have shown that Kureishi's The Black Album (1995) textualizes the pre9/11 political notions of Islamophobia as represented by Runnymede Trust's Report Islamophobia: A Challenge for Us All (1997). Textual analysis of Kureishi's selected novel has shown that he responds to the Western narrative of Islamophobia through his versatile characters such as Riaz, Chad, Hat and Shahid. While the characters of Riaz and Chad in Kureishi's novel comply to the Western narrative of Islamophobia by showing their relevance to characterization of Muslims as described in the Runneymede Trust's report, other characters such as Shahid and Hat collide with and challenge it by showing adaptability and tolerance, especially Hat who presents himself as a good Muslim when showing compassion to Shahid and apologizing for Riaz and Chad's mistreatment. In other words, the assumption has been substantiated, with the help of above discussion, that Kureishi in The Black Alum demonizes Muslims as irrational. At the same time, he also reveals the White racists' behaviour towards Muslims and Islam. Primarily, the characters of Jump (Zulma's friend) and Deedee Osgood are the cases in point. Interestingly, the novel is also seen to justify and provide reasons for the radical behaviour of Muslims while blaming White racist behaviour for the same. For example, the first armed venture of Riaz's group was to save the Muslim Bengali family from severe racist attacks to which the family had been often subjected. The novel is a master narrative providing an apt description of the phenomenon of Islamophobia in the post-Cold war era by apparently complying with the dominant political narrative on Islamophobia; at the same time it offers the hint of negotiation by highlighting the fissures that appeared in the form of racism and immigration crisis.

\section{CONCLUSION}

The New Historicist reading of The Black Album (1995) with reference to the one of the gravest issues of today's world, i-e., Islamophobia, has revealed the role of literary and non-literary discursive formations in its construction and development. The study of the selected literary text against the backdrop of the actual political narrative, i.e., Runneymede Trust's Report about Islamophobia has confirmed the role of prevailing political narrative in its development and construction on the one hand, and has highlighted its struggle to display a sight of subversion on the other. It has been revealed in the analysis that although Kureishi's The Black Album follows the dominant political narrative of Islamophobia, still, in several instances, it can also be seen to deviate from it by providing seemingly logical explanations for the radical and repulsive behaviour of Muslim communities living abroad. By doing so, we suggest that, it offers a sight of subversion, and therefore, demands peaceful and harmonious spaces. Greenblatt's critique that power uses literary and non-literary texts in the formation of 
linguistically and culturally constructed selves has also been re-validated in the context of both Pakistani Anglophone literature and the politics of Islamophobia.

The study also finds that the selected Pakistani novel records the implications of Islamophobia in various forms such as racial violence, expression of religious values, discursive and physical marginalization of Muslims living in the West. Moreover, its treatment of Islamophobia is not only about the representation of anti-Muslim bigotry and violence, but also to forefront some of the pressing issues of the contemporary global world, such as freedom of expression, human rights violations, and racism that are being marginalised on the pre-text of religious extremism. In addition, by analysing the selected anti-Muslim political discourse (co-text) in comparison with the selected literary discourse (text) of the pre-9/11 era, it has been found that the West relied heavily on the discursive formations to promulgate and promote the narrative of Islamophobia. In addition, the study also finds (without reducing the scope of Islamophobia) that the post-Cold war or pre-9/11 era was infused with anti-Muslim bigotry disguised in the problem of racism and immigration crisis.

Lastly, by examining the role of discursive formations in the construction of the narrative of Islamophobia, the present study opens new vistas for the future research on Pakistani Anglophone literature. Examining postcolonial literature against the backdrop of New Historicist theoretical paradigm can also offer insights into the working of normative power structures. Moreover, besides Islamophobia, researchers can also explore other social issues such as gender discrimination, political imbalances -both national and international, and religious discrimination etc., in the Pakistani Anglophone fiction by placing it alongside the actual political discourse of its time.

\section{REFERENCES}

Abubakar, S., Yaapar, M.S. \& Suzana M., (2019). (Un)reading Orientalism in Sherry Jones' The Jewel of Medina. GEMA Online Journal of Language Studies, 19(4). 169-183.

Banerjee, D. (2020). From Cheap Labor to Overlooked Citizens: Looking for British Muslim Identities in Kamila Shamsie's Home Fire. South Asian Review, DOI: 10.1080/02759527.2020.1835141

Brannigan, J. (1998). New Historicism and Cultural Materialism. Hampshire: Macmillan Press Ltd.

Chambers, C. (2011). A comparative approach to Pakistani fiction in English. Journal of Postcolonial Writing. 47(2), 122-134.

Cilano, C. N. (2013). Contemporary Pakistani fiction in English: Idea, nation, state. Routledge.

Curvi, L. (2020). Exclusionary Populism and Islamophobia: A Comparative Analysis of Italy and Spain. Religions. 11(10), 1-21.

Dobie, A. B. (2011). Theory Into Practice: An Introduction to Literary Criticism. Boston, Massachusetts: Cengage learning.

Foucault, M. (1972). The Archaeology of Knowledge (A. M. Sheridan Smith, Trans.). London: Routledge. (Original work published 1969).

Foucault, M. (1980). Power/Knowledge: Selected Interviews and Other Writings 1972-1977 (Ed. Colin Gordon; Colin Gordon et al, Trans.). London: Harvester Wheatsheaf.

Grady, H. (1993). Containment, Subversion, and Postmodernism. Textual Practice. 7(1), 3149.

Greenblatt, S. (1980). Renaissance Self-fashioning: From More to Shakespeare. Chicago and London: University of Chicago Press.

Greenblatt, S. (1981). Invisible Bullets: Renaissance Authority and its Subversion. Glyph. Vol 8. $40-61$. 
Hanif, K. (1995). The Black Album. London: Faber \& Faber.

Huntington, S. P. (1996). The Clash of Civilizations and the Remaking of World Order. NY: Simon \& Schuster.

Huggan, G. (2003). The postcolonial exotic: Marketing the margins. London \& New York. Routledge.

Khan, M. (2011). Islamic Banking Practices: Islamic Law and Prohibition of Ribā. Islamic Studies, 50(3/4), 413-422.

King, B. (2011). Kamila Shamsie's Novels of History, Exile and Desire. Journal of Postcolonial Writing, 47(2), 147-158.

Klaas, B. (2019, March 16). A short history of President Trump's anti-Muslim bigotry. The Washington Post. Retrieved from https://www.washingtonpost.com/opinions/2019/03/15/short-history-presidenttrumps-anti-muslim-bigotry/

Kumar, D. (2012). Islamophobia and The Politics of Empire: The Cultural Logic of Empire. Haymarket Books.

Langah, N. T. (2019). Literary and Non-literary Responses Towards 9/11 South Asia and Beyond. India: Routledge.

Lau, L. \& Mendes, A. C. (2018). Post-9/11 Re-orientalism: Confrontation and Conciliation in Mohsin Hamid's and Mira Nair's The Reluctant Fundamentalist. The Journal of Commonwealth Literature, 53(1), 78-91.

Montrose, L. A. (1997). Professing the Renaissance: The Poetics and Politics of Culture. In Morey, P. (2018). Islamophobia and The Novel. NY: Columbia University Press.

Motlagh, H. M. (2015). The Tempest: A Negotiable Meta-panopticon. Advances in Language and Literary Studies. 6(2), 212-219.

Othman, H. (2014). Islamophobia, The First Crusade and The Expansion of Christendom to Islamic world. World Journal of Islamic History and Civilization, 4 (3). 89-106.

Quin, E. (2018). Deer Crossing. Moose Crossing. Old people Crossing. Children Crossing: Reading Islamophobia Through a Vegan Lens in Kamila Shamsie's Burnt Shadows. The Journal of Commonwealth Literature. 53(1), 109-123.

Rana, J. (2007). The story of Islamophobia. Souls, 9(2). 148-161.

Report, R.T. (1997). Islamophobia: A challenge for us all. London: Runneymede Trust.

Riaz, H. (2017). Racism and Islamophobia: A critique of selected American literary texts. PhD thesis. Fatima Jinnah Women University, Pakistan.

Saad, A. (2020, October 28). Islamophobia: Macron's desperate bid for re-election. ALJAZEERA. Retrieved from https:/www.aljazeera.com/opinions/2020/10/28/islamophobia-as-an-integrationstrategy-in-france

Sadeghi, M. (2017). The systemic benefits of Islamic banking and finance practices: a comparative study. In Global Financial Crisis and Its Ramifications on Capital Markets (pp. 387-400). Springer.

Saleem, A. U (2015). Paracolonialism: A case of post-1988 Anglophone Pakistani fiction. PhD Thesis, University of Bedfordshire, UK.

Shamsie, K. (2017). Home fire. NY: Riverhead Books.

Shamsie, M. (1997). A Dragonfly in The Sun: An Anthology of Pakistani Writing in English. Oxford: Oxford University Press.

Shamsie, M. (2017). Hybrid Tapestries: The development of Pakistani literature in English. Oxford University Press.

Wilson, S. (2007). The Economimesis of New Historicism (Or How New Historicis Displaced Theory in English Literature Departments). Journal for Cultural Research. 11(2), 161174. 


\section{ABOUT THE AUTHORS}

Malik Haroon Afzal is a doctoral student in the School of Humanities, University Sains Malaysia. His current research interests include cultural politics, literary criticism, and Pakistani Anglophone fiction. He has also taught literary theory and criticism, postcolonial literature, and Shakespearean literature at University of Lahore, Gujrat Campus, Pakistan.

Muhamad Rashidi Mohd Pakri is Associate Professor of English in the School of Humanities, University Sains Malaysia. He earned his PhD from the University of Malaya, Malaysia. His research interests include colonial literature and history, postcolonial criticism, biographical writing, and Malaysian English Literature.

Nurul Farhana Low Abdullah is Senior lecturer in the School of Humanities, University Sains Malaysia. She received her PhD from University of Malaya. Her research interests include Shakespearean studies and literary criticism. 